\title{
SLOVENSKO VOJAŠKO ŠOLSTVO, ZAMUJENE PRILOŽNOSTI IN IZZIVI V PRIHODNOSTI
}

SLOVENIAN MILITARY EDUCATION, MISSED
OPPORTUNITIES AND FUTURE CHALLENGES

Professional article

Povzetek Dvajset let v razvoju vojaške organizacije ne pomeni veliko, če ne vidimo napredka, če smo do doseženega preveč kritični in nič ni dovolj dobro. Zelo bi bilo tudi narobe, če bi se naslonili v udobne naslanjače in bili zadovoljni z doseženim. Pogled nazaj mora biti kritičen. Pred leti sem v članku napisal: »Veliko je pomislekov o ustreznosti vojaških šol, pa tudi o ustreznosti sistema vojaškega izobraževanja in usposabljanja /.../ Napačne pa so ocene, da imamo slabo vojaško šolstvo, da je sistem, v katerem učimo in usposabljamo kader, slab. Moja ugotovitev je, da imamo točno takšne šole, kot jih zmoremo oblikovati. Za obdobje, v katerem smo delovali, je sistem tudi povsem zadoščal. Danes želimo več, boljše, drugačno.« Tudi takrat sem v prispevku podal svoj kritični pogled na narejeno in ponujal druge rešitve za doseganje po mojem mnenju bistvenega cilja in ključne stopnje v razvoju - zagotoviti boljšo komplementarnost javnega in internega sistema vojaškega izobraževanja in usposabljanja.

Ključne

Vojaško izobraževanje in usposabljanje, profesionalizacija, vojaški moduli.

besede

Abstract Twenty years in the development of a military organization does not mean much if we are completely satisfied with the progress, if we do not see any progress, if we are too critical of the progress and if we find nothing good enough. It would also be wrong to relax in a comfortable armchair and claim satisfaction with the progress made. One should be critical when looking back. Several years ago, I wrote in one of my articles: »Many question the suitability of military schools as well as the military education and training system... However, the assessments, that our military schools and the system in which we educate and train our personnel are poor, are incorrect. It is in my opinion that we have exactly those types of schools that we are able to shape. This system was completely sufficient for the period in which we operated in. Today people want something more, better, and different.« At 
that time, I also made a critical view of the achievements and offered other solutions to attain what I consider a vital objective and key stage in the development - to provide for a better level of complementarity of the public and internal systems of education and training.

Key words Military education and training, professionalization, military modules.

Uvod in V vseh letih svojega dela na področju teorije in prakse, naj bo to vojaške, pedagoške, izhodišča andragoške, izobraževalno-menedžerske in še kakšne, s katero sem se srečeval, sem prihajal do različnih spoznanj. Verjamem, da imajo podobno izkušnjo tudi drugi. In bojim se, da bi natančnejša analiza našega dela pokazala našo skupno resnico, da ne glede na to, koliko se trudimo in kje opravljamo naloge, z delom pogosto ne uspemo preseči ravni veščine. Izkušenejši od mene bi znali povedati, da je to za vojaško organizacijo povsem razumljivo. »Prav nobene znanosti ni v tem, kar počneš, « me je s svojo kmečko logiko starega rezervnega oficirja velikokrat prekinil oče, ko sem se poskušal malo pogovarjati, kakšne tegobe in izzive pred nas postavlja sodobna vojaška organizacija. Mogoče ima prav. Mogoče pa bi tako moralo biti. Mogoče pa v urejenih vojaških organizacijah z dolgo tradicijo delo na kateri koli ravni ne predstavlja »velike znanosti«. Ljudje s primerno izobrazbo, znanjem in izkušnjami opravljajo svoje delo, ki ima v vojski seveda nekaj posebnosti, odvisno od tega, na kateri ravni pač delaš. Na taktični ravni temelji delo na veščini, na strateški se za kakovostno delo potrebuje drugačno znanje, ki ga častnik pridobi z leti dela na različnih ravneh, na različnih dolžnostih, z izkušnjami in kariernim šolanjem. Žal se za majhne vojaške organizacije brez velike tradicije, kot je naša, opisana logika še ne uresničuje v celoti. Verjetno okolja za tako urejeno delo ni preprosto organizirati. Potrebna sta tradicija in znanje. V naših oboroženih silah pogosto doživljamo, da častniki na taktični ravni za svoje delo potrebujejo veliko posebnega znanja, predvsem za opravljanje nalog na področju razvoja, pa naj gre za znanje s področja kadrovskega menedžmenta, tehnično znanje in druga, ki jih imajo v urejenih sistemih starejši pripadniki vojske z veliko izkušnjami in znanjem, pridobljenim v letih vojaške kariere. Ali splošni in vojaški izobraževalni sistem v Sloveniji to zagotavljata? Ali imajo mladi častniki brez izkušenj možnost, da so uspešni?

V svojem prispevku bom zelo na kratko in zelo strnjeno poskušal pogledati v razvoj sistema vojaškega izobraževanja in usposabljanja (v nadaljevanju VIU), in sicer v dveh fazah - razvoj pred profesionalizacijo in po njej. Sistem z zagotavljanjem primernega znanja, spretnosti in navad posameznikom na vseh ravneh vojaške organizacije po mojem prepričanju neposredno vpliva na urejenost delovnega okolja in razmere v vojaški organizaciji. Osrednji predmet moje obravnave bo programski vidik VIU, ki je po moji presoji bistven. Saj ne, da me v sistemu ne zanimajo tudi drugi elementi, vendar jih v tako kratkem besedilu ne morem obravnavati.

$\mathrm{Na}$ obeh opisanih stopnjah razvoja sistema VIU smo imeli priložnosti, ki jih po mojem mnenju nismo v celoti izkoristili. Priložnosti smo celo zapisali, uresničitev 
pa pogosto ni bila popolna. Menim, da je največkrat odpadlo bistvo oziroma vsebina, večino ustvarjalnega znanja, energije in moči pa smo trošili za organizacijo, zunanjo obliko itn.

Prispevek, ki je pred vami, sem poskušal napisati bolj analitično, pa sem pozneje ugotovil, da bi se spremenil v naštevanje nekakšnih podatkov zadnjih dvajsetih let. Ni moj namen paziti na datume in posamezne dikcije, zato sem se odločil esejistično opisati svoj pogled na prehojeno pot in predstaviti pogled na model sistema VIU, ki bi ga na podlagi veljavne zakonodaje in razmer v družbi lahko ustvarili. Zaradi tega pristopa je prispevek (morebiti celo preveč) osebno obarvan.

Menim, da je v mladih, na hitro razvitih in kompleksnih sistemih, torej tudi $\mathrm{v}$ Slovenski vojski, na več ravneh mogoče čutiti slabosti, ki so posledica pomanjkanja eksplicitnega znanja. To se verjetno dogaja tudi zaradi slabosti v sistemu VIU, ki bi vojsko moral podpirati.

Pred nekaj leti sem v eni izmed vročih razprav o tem, kaj bi posamezniki v vojski in tudi $\mathrm{v}$ ustanovah javnega izobraževalnega sistema morali narediti, da bi razvoj sistema VIU zajel veter v jadra in dosegel pravo dinamiko, doživel presenečenje. Če na kratko parafraziram razpravo: »Zaman se trudite. Politika določa sistem VIU in politika bo odločala in vojski povedala, kaj naj želi, kaj naj naredi.«

Poglejmo torej posledice teh odločitev. V javnem sistemu izobraževanja v Republiki Sloveniji ni vojaških izobraževalnih ustanov. Posameznik, ki želi postati pripadnik SV, mora imeti ustrezno izobrazbo in si po zaposlitvi v Slovenski vojski v Centru za

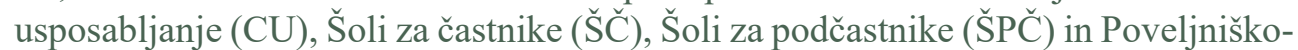
štabni šoli (PŠŠ) pridobiti vojaško znanje oziroma vojaško izobrazbo. Osrednja vojaška izobraževalna ustanova, s stališča vojske je seveda interna, je Poveljstvo za doktrino, razvoj, izobraževanje in usposabljanje (PDRIU) ${ }^{1}$. V zadnjem obdobju smo razvili in v javni sistem vključili dele programov VIU, ki se sicer izvajajo v interni ustanovi. Najpomembnejši dosežki so ${ }^{2}$ :

- od leta 2003 v Sloveniji poteka šolanje pilotov, ki je v strokovnem delu vključeno v Fakulteto za strojništvo. Vključeno je tudi opravljanje strokovne prakse, ki je po eni strani del fakultetnih obveznosti študentov, po drugi pa je to šolanje bodočih pilotov vojaškega letalstva SV;

- že dalj časa poteka tudi vključevanje programov vojaškega šolanja v program Fakultete za družbene vede oziroma njene Katedre za obramboslovje. V tem trenutku se kot del programa študija politologije, smer obramboslovje, izvaja

\footnotetext{
PDRIU skrbi za organizacijo, razvoj in izvajanje programov VIU. PDRIU je torej nosilec internega VIU ter raziskovalnega in razvojnega dela in tehnološkega razvoja vojske. Skrbi tudi za uvajanje novega vojaškega znanja prek šolskega sistema v prakso. To je organ poveljevanja in kontrole zavodov, ki jih predstavljajo šole in centri v njegovi sestavi, ter drugih podrejenih organizacijskih enot. V okviru PDRIU delujejo še Šola za tuje jezike, Letalska šola, Gorska šola, Knjižnično-informacijski center in Vojaški muzej.

2 Glej tudi: Motiv, Poročilo o izvedbi ciljnega raziskovalnega programa »Model terciarnega izobraževanja za vojsko«. 2007. UP Fakulteta za management Koper, november 2007.
} 
program s tako imenovanim vojaškim modulom. Del tega modula so posebni predmeti, drugi del pa opravljanje strokovne prakse v SV (vojaški praktikum), med katero pravzaprav poteka temeljno vojaškostrokovno usposabljanje (TVSU);

- na Poveljniško-štabni šoli je del programa poveljniško-štabnega šolanja druge stopnje za častnike vključen v študij specializacije oziroma študij druge bolonjske stopnje (na Fakulteti za družbene vede, Katedri za obramboslovje v Ljubljani, na Fakulteti za logistiko v Celju in Krškem, občasno tudi na Fakulteti za management v Kopru);

- na Višji prometni šoli je uveden študij logistike, v katerega je vključen program poveljniško-štabnega šolanja druge stopnje za podčastnike. Program je nov in pomeni začetek razvoja modela poveljniško-štabnega šolanja podčastnikov, vključenega $\mathrm{v}$ javni sistem izobraževanja.

Veliko dlje nismo prišli. V uvodu poglejmo le še bistvene teoretične okvire, ki jih potrebujemo za razumevanje članka. Kaj razumem kot vojaško izobraževanje in usposabljanje (Furlan in skupina avtorjev, 2006, 35): »VIU sta procesa pridobivanja in razvijanja posebnih in funkcionalnih vojaških znanj, sposobnosti, veščin in navad za izvajanje nalog za potrebe vojaške obrambe in drugih nalog Slovenske vojske.«/.../ »Slovenska vojska razvija sodobno organiziran, celovit in enovit sistem VIU, ki je ob kvalitetnem vodenju sposoben izvesti naloge na področju VIU in je primerljiv s sistemi vojsk v zavezništvu ter povezljiv z javnim izobraževalnim sistemom.« Pri tem »/.../ VIU posameznika $\mathrm{v}$ institucijah VIU doma in $\mathrm{v}$ tujini ter $\mathrm{v}$ tujih javnih izobraževalnih in drugih institucijah zagotavlja pridobivanje vojaške izobrazbe, vojaških in drugih strokovnih znanj ter vojaške in druge strokovne usposobljenosti, pridobivanje vojaških poklicnih kvalifikacij, kontinuirano dopolnjevanje znanj ter oblikovanje posameznika v smislu razvijanja njegovih sposobnosti, iniciativnosti, samostojnosti ter profesionalnega odnosa do opravljanja vojaškega poklica.« Temeljne definicije VIU so opredeljene na doktrinarni ravni in se praktično ne spreminjajo.

Kot že rečeno - sistem VIU ima več podsistemov, elementov, mogočih in potrebnih je več vidikov obravnave. $V$ tem članku se $z$ institucionalnim pogledom na sistem ne bom posebej ukvarjal, čeprav žal lahko ugotovim, da ima v praksi prav ukvarjanje z institucionalizacijo VIU največkrat glavno vlogo. Najmanj sprememb (po ukinitvi služenja vojaškega roka) pravzaprav doživlja vsebinski vidik sistema VIU³ , ki je (obravnavan kot interno izobraževanje in usposabljanje) vsebinska in organizacijska nadgradnja procesov splošnega (javnega) izobraževanja in usposabljanja. To je organiziran, načrten in ciljno usmerjen proces pridobivanja in razvijanja posebnega in funkcionalnega vojaškega znanja, sposobnosti, spretnosti in navad za izvajanje nalog vojaške obrambe.

Pomembno se mi zdi, da opredelimo tudi termin znanje, ker je nujno, da vsaj na splošni ravni razlikujemo med implicitnim in eksplicitnim znanjem (Andragoška spoznanja 2/2002: Brečko, 3). Implicitno je znanje, ki ga posamezniki »nosimo v

3 Več o tem Toš, D., 2007. Obrambno in varnostno izobraževanje v nacionalnem obrambno-varnostnem sistemu $R$ Slovenije, seminarski delo. Poljče, 2003. 
glavah«, ki nastane z delom, izkušnjami, z leti ... Eksplicitno pa je tisto znanje, ki »je zapisano v knjigah«, lahko bi rekli, da je kakor koli zapisano na različnih medijih (pri tem ne gre razumeti, da je eksplicitno znanje vse, kar je zapisano, temveč morajo za zapisano veljati neka pravila nastanka, kot so upoštevanje raziskovalnih in znanstveno utemeljenih metodologij, referenc ...) in dostopno drugim. Ni mogoče v celoti pritrditi teoriji, da je eksplicitno znanje pogoj za implicitno ali obratno, prav tako je po teoriji »/.../ kaj je prej - jajce ali kokoš /.../ « težko ugotoviti, katero je po hierarhiji višje. Je pa dejstvo, vojaška organizacija brez eksplicitnega znanja ne preživi, res pa je tudi, da je vojaška organizacija načeloma utemeljena na implicitnem, izkustvenem znanju, ki se po ustreznih poteh (v zadnjem obdobju rečemo temu »učenje iz izkušenj«) ovrednoti in zapiše, predpiše ... Najvišji starešina je najbolj izkušen, njegovo implicitno znanje je najbogatejše.

\section{KAJ PO MOJEM MNENJU SPLOH POTREBUJEMO}

To je ključno vprašanje, na katerega je po mojem mnenju vojaška stroka kar nekajkrat odgovorila, do sprememb ali bolje rečeno pomembnejših premikov k rešitvam na podlagi teh ocen pa menim, da še nismo prišli.

Integracijo vojaškega internega in javnega izobraževanja smo začeli intenzivneje uresničevati z Obveznimi usmeritvami za preoblikovanje in razvoj sistema VIU v SV (obvezne usmeritve) ter s Konceptom sistema VIU v SV (koncept). Pričakovati je bilo, da bodo zastavljeni cilji, predvsem zaradi hkratnega zelo izpostavljenega procesa profesionalizacije vojske, v celoti doseženi. Moje mnenje je, da je uresničitev koncepta VIU na splošno dobra (institucionalizacija, organizacija oziroma koncentracija razpoložljivih virov itn.), na nekaterih delih pa zelo šibka. Analize so pokazale, da je nekatere cilje treba prenoviti, razširiti itn. Ugotovljeno je bilo ${ }^{4}$, da je v okviru formalnopravnih podlag treba nadgraditi sedanje stanje in zagotoviti razvoj, ki bo omogočil uvedbo takšnega sistema VIU, ki bo javno veljaven ter bo sistemsko in celovito pokril izobraževalne potrebe SV, vključene v sistem javnega izobraževanja, na več ravneh kot je to določal koncept, in sicer na ravni srednješolskega izobraževanja oziroma srednjega strokovnega izobraževanja, na ravni višjega strokovnega izobraževanja (raven 6/I), na ravni dodiplomskega (visokošolski študijski programi in univerzitetni študijski programi na prvi bolonjski stopnji, raven 6/II ) ter na ravni podiplomskega izobraževanja (magistrski študijski program na drugi bolonjski stopnji, raven 7).

Zamisel je bila, da bi v prvi fazi zagotovili formalno in stvarno vključitev delov vojaških izobraževalnih programov v javni izobraževalni sistem ter razširili krog partnerjev (domačih in v tujini) za izvajanje vojaškega izobraževanja v javnem izobraževalnem sistemu.

4 Glej tudi: Izhodišča za oblikovanje v sistem javnega izobraževanja integrirane vojaške izobraževalne institucije (MO RS, 603-105/2008-3 z dne 16. 8. 2008). 
Tu se je (ponovno) oblikovala tudi zamisel, ki jo je zelo malo posameznikov želelo ali moglo razumeti, o oblikovanju vojaške izobraževalne ustanove, vključene v javni izobraževalni sistem. To ustanovo smo (med drugimi možnostmi) delovno poimenovali vojaški izobraževalni center. Zagotavljal naj bi:

- delovanje integriranih programov VIU v sistemu javnega izobraževanja na vseh ravneh;

- tesnejše povezovanje slovenske javne vojaške izobraževalne ustanove s tujimi javnimi vojaškimi izobraževalnimi ustanovami;

- ohranitev povezave z internim vojaškim izobraževalnim sistemom;

- uresničevanje nalog javne vojaške znanstvenoraziskovalne ustanove.

Zakaj takšna odločitev? Ne vem natančno, kaj so takrat razmišljali v vojaškem vrhu, lahko predstavim svoj pogled na ta obrat. Ko sem analiziral stvarne možnosti za uresničitev zamisli, da bi vojaške programe izvajali v sodelovanju z javnimi izobraževalnimi ustanovami brez svoje, v javnem izobraževalnem sistemu priznane ustanove, ko sem sodeloval na številnih delovnih srečanjih in sestankih s predstavniki javnih izobraževalnih ustanov, sem prišel do spoznanja, da je mogoče zagotoviti večino virov in izpolniti večino pogojev za izvedbo programov. Mogoče je bilo celo oblikovati pričakovanja in zahteve po lastni vsebini, kar, po pravici povedano, v preteklosti ni bilo pravilo, nosilci predmetov so bili pripravljeni podajati vsebino točno tako, kot smo mi določili in pričakovali. Vse ustanove, brez izjeme, so postavljale le en pogoj: »Ne posegajte $\mathrm{v}$ programe, ki jih že izvajamo. Ti programi so urejeni, financira jih država /.../ pustite to pri miru, o tem se ne pogovarjamo /.../« To je dobesedno pomenilo, da bodo programe izvajali in zagotovili javno priznano izobrazbo, vendar je treba za njihovo uresničitev zagotoviti finance iz vojaškega proračuna, deloma ali $\mathrm{v}$ celoti. To seveda za politiko in družbo ni bilo izvedljivo in sprejemljivo. V resnici pa so nekateri v javnem izobraževalnem sistemu že prej izvajani programi VIU, po mojem mnenju neupravičeno, ostali financirani iz vojaškega proračuna. Sklepam, da je bilo narobe to, da nismo zagotovili, da bi se politična raven odločanja tu vmešala in da bi bila na vladni ravni zagotovljena ustrezna stališča o VIU, ki bi bila obvezujoča tudi za druga ministrstva, odgovorna za delovanje javnega izobraževalnega sistema. Mislim, da nam je na tej stopnji zavedanja problema ostala edina mogoča rešitev - spodbudimo razvoj javne vojaške izobraževalne ustanove, ki se bo vključila $\mathrm{v}$ javni izobraževalni sistem, tam sama uveljavila programe VIU in si »izborila in odtrgala« del potrebnih finančnih virov za izvedbo programov, vključenih v javni izobraževalni sistem na vseh ravneh šolanja. Očitno bi bilo le tako mogoče zagotoviti za družbo sprejemljivo obliko in način zagotavljanja virov - vse drugo, obseg dejavnosti, vsebina, modularni pristop k vojaškemu izobraževanju, medprogramska in medfakultetna izmenjava predmetov, predavateljev, kreditnih točk itn., vse bi ostalo enako. Delež financiranja vojaškega izobraževanja iz vojaškega proračuna pa bi bil tako bistveno manjši in bolj sprejemljiv.

Zadeva je bila za večino stroke in vojske presenečenje, mislim, da je bila na splošno tudi na MO napačno razumljena. Tudi nekatere javne izobraževalne ustanove so zamisel interpretirale kot nostalgijo okorelih oficirjev in neupravičeno kritiko 
njihovega dela. Projekt je bil razumljen ali interpretiran kot poskus vračanja v devetdeseta leta (zamisel o vojaški akademiji) in je zato tudi propadel, prepričan sem tudi, da je precej zavrl ambiciozno zastavljeni razvoj. Škoda.

Pred tremi leti smo v izhodiščih za oblikovanje vojaške izobraževalne ustanove, integrirane v sistem javnega izobraževanja, zapisali, da poleg drugega od projekta pričakujemo še, da:

- se bosta v SV zaradi obsega posebnih potreb vojske (veščinski del VIU, specialistično izobraževanje in usposabljanje itn.) ohranjala sistem internega VIU in interna vojaška izobraževalna ustanova;

- bo PDRIU kot glavna ustanova v sistemu VIU ostal oblikovan kot osnovna struktura za vodenje, usmerjanje in izvajanje izobraževalnega menedžmenta, menedžmenta znanja ter oblikovanje programov in procesov osnovnega vojaškostrokovnega izobraževanja in usposabljanja (OVSIU) posameznikov (za pridobitev poklica - nacionalnih poklicnih kvalifikacij), in sicer tako, da bodo poleg vojaške izobrazbe, zagotovljene v javnem izobraževalnem sistemu, zagotovljeni tudi pridobivanje specialističnega in posebnega strokovnega znanja, posebna vojaškostrokovna usposobljenost za opravljanje nalog v SV ter ustrezna usposobljenost za izvajanje nalog v pogodbeni rezervi. Interno vojaško izobraževanje se usmeri predvsem v zagotavljanje pridobivanja vojaške veščine in vojaškega veščinskega znanja na vseh ravneh vojaškega izobraževanja;

- znotraj sistema ostaja VIU nosilec oblikovanja tistega dela programov in procesov dopolnilnega strokovnega (nadaljevalnega, funkcionalnega in dodatnega) izobraževanja oziroma usposabljanja posameznikov (poklicno izpopolnjevanje), ki bo potekalo $\mathrm{v}$ internem sistemu in bo odpravljalo pomanjkljivosti pri opravljanju nalog; omogočilo dopolnjevanje znanja do zahtevane stopnje ter nadgradnjo znanja in veščin za opravljanje poklicev na zahtevnejših ravneh; zagotavljalo VIU različnih vrst za neposredno opravljanje povsem določenih del, vlog, funkcij ali nalog na konkretnih delovnih mestih v SV; omogočalo pridobivanje dodatnih znanja in veščin za kakovostnejše opravljanje poklicev in za prehod na civilno delo; v sodelovanju s pristojnimi organi in javnim izobraževalnim sistemom zagotavljalo pridobitev poklicnih licenc kot pogojev za opravljanje nalog na določenem delovnem mestu in podpiralo karierni razvoj posameznika;

- mora sistem VIU tudi voditi, usmerjati in uresničevati programiranje ter usposabljanje skupin, poveljstev in enot ter posameznikov na dolžnosti, tako da bosta zagotovljena nenehno preverjanje dosežene stopnje usposobljenosti in večja pripravljenost poveljstev in enot;

- je pomembna naloga zagotavljati povezavo z javnim izobraževalnim sistemom, tako da bosta vojaški in javni izobraževalni sistem programsko povezana in bo mogoče hkrati z vojaškim obiskovati javne izobraževalne programe ter pridobiti javno priznano stopnjo izobrazbe oziroma tako, da bo sistem VIU nadgradnja javnega izobraževalnega sistema;

- bi se $\mathrm{v}$ sistemu VIU ohranili in nadaljevali interni raziskovalna in razvojna dejavnost, ki bosta poleg razvoja sistema VIU zagotavljali tudi del razvojnoraziskovalne dejavnosti na področjih vojaških znanosti, stroke, doktrin, organizacije in 
sistemov ter na področju izbora oborožitve in vojaške opreme, in sicer na temeljih dosedanjega razvoja ter skladno z vizijo razvoja vojaške obrambe. Vse seveda v povezavi z javno izobraževalno ustanovo ustrezne ravni, ki bi bila nosilec znanstvenoraziskovalne dejavnosti;

- bi bile v sistemu VIU zagotovljene možnosti različnih oblik vojaškega usposabljanja državljanov (prostovoljno služenje vojaškega roka mladine, strokovnjakov z različnih področij delovanja v državnih organih, gospodarskih družbah in podobno), ki si tako pridobijo znanje z vojaškega in obrambnega področja.

Izhodišča so določala tudi, da je treba zagotoviti, da se v projektu izkoristijo vse prednosti, ki jih za uresničitev že določenih ciljev in nalog VIU posameznika ponujajo javni izobraževalni sistemi v Sloveniji in tujini.

Stališče je bilo, da je za razvoj vojaških poklicev nujno treba na srednji strokovni ravni uveljaviti vojaške module, in sicer na dveh temeljih. Prvi je razvoj strokovnih delov programov srednjega strokovnega izobraževanja, s katerim je treba zagotoviti razvoj vojaških poklicev predvsem na področju tehničnih in naravoslovnih strok. Drugi temelj pa je na srednji strokovni ravni praktični del programov srednjega strokovnega izobraževanja, v okviru katerega bi se s TVSU zagotavljali usposabljanje in urjenje praktičnih vojaških veščin.

Na ravni višjega strokovnega izobraževanja je treba zagotoviti, da se v javni izobraževalni sistem vključi program višje šole za podčastnike, ki po eni strani zagotavlja razvoj skupnega znanja na višji strokovni ravni šolanja podčastnika, po drugi pa vključitev poveljniško-štabnega šolanja podčastnika (vseh treh ravni) v javni izobraževalni sistem.

$\mathrm{Na}$ ravni visokega strokovnega in univerzitetnega izobraževanja bi se razvijal nov program študija, ki bi bil temeljni program izobraževanja častnika s skupnim jedrom znanja. Program bi bil organiziran v vojaške module, ki bi jih kot izbirni del končali častniki drugih rodov in služb, ki bi bili za specialistično vojaško stroko primerni. Programi bi potekali na javnih izobraževalnih ustanovah, skladno s predpisanim vojaškim poklicem. Na ravni podiplomskega izobraževanja se sedanji programi na dodiplomski stopnji nadgradijo s podiplomskim študijem, tako da omogočajo vojaško izobraževanje častnika na poveljniško-štabnem izobraževanju na vseh treh ravneh in hkratni študij vojaških modulov po programih podiplomskega izobraževanja.

Glavni nosilec šolanja temeljnih vojaških veščin v Slovenski vojski bi morali ostati centri za usposabljanje za raven TVSU, ŠPČ za raven osnovnih vojaških veščin in podčastnika, ŠČ za raven temeljnega vojaškega znanja in veščin za častnike ter PŠŠ za raven poveljniško-štabnega šolanja starešin SV. Hkrati bi ti vojaški centri in šole ostali osnovni nosilci sodelovanja z javno vojaško izobraževalno ustanovo ter drugimi javnimi izobraževalnimi ustanovami pri izvajanju v javni sistem integriranih programov vojaškega izobraževanja. 
Dokument je po mojem mnenju odkrito podprl tudi nadaljnji razvoj sistema štipendiranja, predvsem študentov, ki se izobražujejo v programih vojaškega izobraževanja in usposabljanja, kar bi moralo biti temeljno načelo novačenja častniškega kadra.

\section{MEJNIKI V PRILOŽNOSTIH IN OPREDELITEV ZAMUD}

Vojaški sistem kot celota, tudi sistem VIU in znotraj njega procesi VIU, je od osamosvojitve (del programov se je izvajal že prej) doživljal pomembne spremembe. Vsako obdobje ima svoje značilnosti, žal po mojem mnenju tudi nekaj zamujenih priložnosti.

\subsection{Od učnih centrov do poklicne vojske}

Katere so glavne značilnosti tega obdobja, ki je trajalo od ustanovitve učnih centrov (1991) do konca naborniške vojske (2003)?

Če ostanem na splošni ravni in zanemarim posebne oblike usposabljanja poklicnih struktur SV (specialne sile itn.) lahko rečem, da pri usposabljanju vojakov v tem obdobju poznamo dve kategoriji. Na eni strani so se usposabljali vojaki stalne sestave, na drugi pa vojaki naborniki.

Ugotavljam, da med obema kategorijama ni pomembnih razlik v organizaciji ali vsebini. Natančna analiza posameznih programov bi sicer pokazala nekaj vsebinskih ali organizacijskih odklonov, drugače pa je za celotno obdobje značilno, da usposabljanje vojakov vsebinsko in organizacijsko temelji na izkušnjah in znanju, pridobljenih v nekdanji skupni vojski.

Pri VIU podčastnikov se v obravnavanem obdobju zgodi najmanj sprememb. Podčastnike je slovenska vojska v organizacijskem pa tudi vsebinskem smislu dobivala na način, ki je bil primerljiv s tistim v nekdanji skupni državi. Največja slabost tega sistema je bila v načinu usposabljanja, kar se je najbolj pokazalo pozneje, ko sta se začela povečevati področje dela in odgovornosti podčastniškega zbora in skupni delež v številu zaposlenih. V obdobju pred ukinitvijo naborniške vojske smo poznali šolo za podčastnike stalne sestave in usposabljanje (tečaj) nabornikov za poveljnike oddelkov. Programski in vsebinski del sta bila povsem neprimerljiva, temu primerno pa tudi raven vojaškega znanja in obseg kompetenc, ki jih je imel podčastnik stalne ali podčastnik rezervne sestave SV.

Prav tako je bilo pri šolanju častnikov. Ne moremo sicer reči, da je bilo v vsebini veliko razlik med šolanjem častnikov stalne in častnikov rezervne sestave (šolanje je potekalo nekako vzporedno, le za STAS se ni končalo v pol leta). Vsekakor pa je temeljilo na podobnih izhodiščih, kot jih je imela vojska nekdanje skupne države. Že površna analiza sistemov novačenja častniškega zbora pokaže, da pravzaprav ni šlo za neko naključno kontinuiteto nam znanega, temveč za opredelitev in izbor sistema vojaškega šolanja, ki je bil za politiko in stroko takrat sprejemljiv. Znano je, da je v 
sodobnih vojskah tak sistem primerljiv z enim izmed načinov pridobivanja častniškega zbora (večina sodobnih držav kombinira več sistemov novačenja in vstopa $\mathrm{v}$ častniški zbor: prek javno priznane vojaške akademije; z ulice z ustrezno stopnjo izobrazbe in vključevanjem v veščinsko šolanje itn.). V nekaterih vojskah je sistem veščinskega šolanja dela častniškega zbora zelo cenjen in nepogrešljiv (znano je, kako cenijo tako šolane častnike v Veliki Britaniji in še kje). Treba je seveda priznati, da smo ena redkih držav, ki je imela le tak način vključevanja v častniški zbor in da je ta sistem doživljal razcvet v vojaških organizacijah, v katerih razvijajo vseživljenjski karierni model častnika.

Nekaj izzivov, ki jih morebiti nismo izkoristili:

- vojska je temeljila na množičnosti in kakršne koli razvojne težnje se takrat žal niso dotaknile vojakov in podčastniškega zbora;

- razvojni potencial SV se je do začetka profesionalizacije na področju VIU v večjem delu ukvarjal s častniškim zborom. Dokumenti tistega časa so zelo zanimivi. Večina zamisli je bila obravnavana na prvem posvetu o izobraževanju častnikov SV, o čemer priča tudi Zbornik (Ljubljana, 1995). Velika škoda je, da se večina sklepov tega posveta ni uvedla v vojaški izobraževalni sistem. Zamisli nakazujejo številne rešitve, od javne vojaške izobraževalne ustanove do prepričanja, da ni ničesar, kar bi bilo treba spremeniti. Vmes so zamisli o vojaških katedrah na izbranih fakultetah, ki so bile zelo blizu zamislim o vojaških modulih, ki so se pravzaprav uveljavili v obdobju tik pred začetkom profesionalizacije;

- poveljniško-štabno šolanje častnikov in druge oblike funkcionalnega izobraževanja in usposabljanja ne doživljajo posebnih razprav o razvoju, čeprav sta se prav v okviru prej omenjenega posveta gosta in razpravljavca iz Nemčije in Avstrije dotaknila tudi te problematike.

\subsection{Profesionalizacija}

Povsem razumljivo mi je, da je obdobje profesionalizacije z razvojem profesionalne vojske pomembno posegalo tudi v razvoj sistema VIU. Ne nazadnje je del tako imenovanega projekta PROVOJ v pomembnem delu posegel na področje VIU:

- večji del projekta PROVOJ se je v sistem VIU uvedel prek obveznih usmeritev za preoblikovanje in razvoj sistema VIU, drugi del pa je potekal s posebnim projektom, katerega rezultat so ustanovitev in delovanje Centra za usposabljanje (CU) ter Centra za bojno usposabljanje poveljstev in enot (CBU). Osvetliti bom poskušal neizkoriščene priložnosti in slabosti pri delovanju CU, ki je mojem mnenju odlična in dobro organizirana ustanova, povsem primerljiva s podobnimi v tujini. Žal pa smo se osredinili le na en del poslanstva take ustanove. Da bi racionalizirali delovanje SV, bi to ustanovo morali reorganizirati, tako da bi sprejela tudi druge izzive, ne le izvajanje programa TVSU. Menim, da bi ustanova morala najti ter razvijati trdno in skupno jedro z enotami SV, ki so zdaj odgovorne za osnovno vojaško usposabljanje za vojaške poklice. Prav v tej slabosti se kaže temeljna neizkoriščena priložnost tega obdobja - uvajanje vojaških nacionalnih poklicnih kvalifikacij, ki bi vojaškemu delu vojske zagotovile bistveno večjo konkurenčnost na notranjem in zunanjem trgu delovne sile. Ker ta del projekta 
ni uresničen, osnovno izobrazbo še vedno povsem zanemarjamo pri odločanju, kakšno »vlogo« bo posameznik v vojski imel. Menim, da je za vojsko še vedno sprejemljivo, da ima nekdo najmanj zahtevano stopnjo izobrazbe, kakšna je ta izobrazba, pa je pomembno v (pre)majhnem delu odločanja o karieri pripadnika. Temu primeren je tudi poznejši odnos do vojaške usposobljenosti. Prepričan sem, da je prav v tem odnosu do znanja ena večjih slabosti naše vojske. Po eni strani srečujemo visoko zavedanje o nujnosti, da posameznik obvladuje sebe, orožje in opremo, ki ju upravlja, ter okolje v katerem deluje, po drugi pa popolno zapostavljanje znanja, ki je podlaga posameznikovi splošni izobrazbi, razgledanosti itn. Zapostavljanje izobrazbe je značilno le za množične naborniške vojske, v katerih posameznik znotraj vojaške organizacije prevzema bistveno manjšo, zelo ozko (povsem veščinsko) vlogo, kot je to znano oziroma nujno za poklicne vojske;

- z necelovito uvedbo obveznih usmeritev in izhodišč za oblikovanje $\mathrm{v}$ sistem javnega izobraževanja vključene vojaške izobraževalne ustanove so po mojem mnenju ostale nekatere pomanjkljivosti:

- zamudili smo urejanje in gradnjo sistema srednješolskega oziroma srednjega strokovnega izobraževanja vojakov in podčastnikov in v tej povezavi zagotavljanje nacionalnih poklicnih kvalifikacij ter visoko strokovno in tehnično izobraženega kadra, nujnega za delovanje in vzdrževanje sodobnih, sofisticiranih in tehnološko visoko zahtevnih oborožitvenih sistemov,

- razvoj poveljniško-štabnega šolanja podčastnikov ne napreduje,

- razvoj v javni sistem vključenega dodiplomskega in podiplomskega šolanja častnikov je zastal na stopnji, ki ne kaže želenega končnega stanja,

- interna razvojno-raziskovalna dejavnost ne daje ustreznih rezultatov,

- razvoj sistema in rezultati delovanja znanstvenoraziskovalne dejavnosti na področju vojaške znanosti in vojaških ved, teorije in prakse vojne veščine, vojaških sistemov in vojaške organizacije so po moji presoji preslabi.

\section{MOJ POGLED NA IZZIVE}

Kaj nas čaka? Kako nadoknaditi zamujeno, kako in kje nadgraditi izvedeno? Katere so prave smeri? Kje so razlogi, kakšne bi morale biti odločitve? V zadnjem obdobju interni izobraževalni sistem SV po mojem mnenju kaže vedno večje slabosti. Veliko preveč je treba vlagati organizacijskih in kadrovskih naporov, da ohranjamo doseženo raven kakovosti uresničevanja nalog. Napredka na področju razvoja sistema VIU po mojem praktično ni.

Glavni razlogi za integracijo dela programov vojaškega internega VIU v javni sistem izobraževanja se pojavljajo s potrebo oziroma zahtevo po konkurenčnosti vojaškega strokovnjaka na trgu delovne sile. Tu je seveda še nekaj drugih vidikov in razlogov. $\mathrm{Z}$ ustvarjenjem povezav internega $\mathrm{v}$ javni izobraževalni sistem bi se prav gotovo povečala kakovost izobraževanja, ustvarjena bi bila širša konkurenca med strokovnjaki in izvajalci. Ne smemo zanemariti, da bi se tako lahko izognili vplivu »dnevnih potreb poveljnikov«, za katere je znano, da na kakovost izvajanja programov zaradi 
operativnih potreb vojske ne vplivajo ravno pozitivno, s čimer bi se prav gotovo zagotavljala stabilnost posameznih izobraževalnih programov.

V obdobjih velikih naborniških vojsk so bili starešine strokovnjaki za poveljevanje $\mathrm{v}$ boju, pedagogi, andragogi, poveljniki in vzgojitelji ${ }^{5}$. S profesionalizacijo in novo vlogo vojske se kompetence, znanje in pristojnosti starešin spreminjajo. Danes starešine opravljajo dolžnosti, zaradi katerih so pogosto v samostojni vlogi na terenu, so v položajih, ko morajo razumeti splošno družbeno okolje in obvladovati stike z javnostjo, vse bolj pa morajo razumeti in obvladati tudi novo tehnologijo, kar je glede na to, da smo na prehodu v informacijsko družbo, nova zahtevna naloga. Izziv je tudi določitev znanja in usposobljenosti, potrebnih na posameznih področjih, ki morajo vključevati vse od splošnega do veščinskega znanja. Do zdaj so bile glavne vsebine OVSIU starešin voditeljstvo, veščina poveljevanja in vodenje enot. Že v sedanjih programih smo ugotavljali pomanjkljivosti, na primer pri uresničevanju vzgojnih funkcij v VIU, pomanjkljivo tehnično usmeritev izobraževanja in usposabljanja častnikov itn.

Menim, da je danes glavno vprašanje vzpostavljanje ravnovesja med tehnično in družboslovno usmeritvijo vojaškega starešinskega kadra. Uveljavljeno je stališče, da morajo imeti častniki splošno znanje z družboslovno-humanističnih področij, nadgrajeno s tehničnim, informacijskim in drugimi vrstami znanja, spretnosti in usposobljenosti.

Z uveljavitvijo spremenjene vloge podčastniške strukture se v resnici zožuje delovno področje častnikov. Podčastniki so nosilci neposrednega vodenja, delitve neposrednega dela, veščinskega individualnega usposabljanja in rutinskih nalog. Povečala se je možnost, da se častniki še bolj usmerijo v posredno vodenje ter štabne dejavnosti in strokovnost na višji ravni. Hkrati pa se veča potreba po širjenju podčastniškega izobraževalnega področja.

Prepričan sem, da je pomanjkanje posebne vojaške raziskovalne in znanstvenoraziskovalne dejavnosti na takšni stopnji, da je nujno ukrepati, poiskati je treba nove rešitve. Prepričan sem, da je na tem posebnem področju, predvsem zaradi nerazvitih posebnih vojaških strok in pomanjkljive tradicije, iskanje primernih rešitev najtežje. Svojo razvojno in raziskovalno dejavnost ter razvoj vojaške stroke je treba nadgraditi znotraj lastnega sistema VIU, znanstvenoraziskovalno dejavnost, od veščinske in tehniške do znanstveno-teoretične ravni, pa v okviru izobraževalnih ustanov, ki izvajajo dodiplomske in podiplomske programe vojaškega izobraževanja. Treba je biti vztrajen, strpen in iskati ter graditi dolgoročno zastavljeno vizijo. Na tej podlagi pride tradicija.

Več o tem tudi Toš, D., 2008. Vojaški izobraževalni sistem - realnost ali muha enodnevnica. V: Bilten Slovenske vojske, maj $2008-10 /$ st. 1, stran 97-121. 


\subsection{Visokošolsko izobraževanje}

Možnosti za vključitev vojaškega izobraževanja v javni sistem na stopnji visokošolskega izobraževanja:

- nadaljnji razvoj programov, vključenih v javne visokošolske izobraževalne ustanove, ki bodo zagotavljali:

- razvoj in vključitev programa izobraževanja za častnika SV,

- razvoj in vključitev vojaških predmetov in vsebin, ki bodo osrednji del navedenega študija, hkrati pa izbirni del (vrednoten s kreditnimi točkami) za študij na drugih fakultetah, ki bodo izobraževale druge profile častnikov SV,

- razvoj in vključitev programov izobraževanja častnikov na drugi stopnji poveljniško-štabnega šolanja, ki bo hkrati veljalo kot študij na drugi bolonjski stopnji;

- vključitev splošnega in teoretičnega dela šole za častnike (ustrezno vrednotenega s kreditnimi točkami) v programe študija, vključene v javni sistem izobraževanja, po katerih se izobražujejo bodoči častniki;

- vključitev TVSU kot del obvezne delovne prakse (ki ima ustrezen del kreditnih točk) vključene v javni sistem izobraževanja v vse programe študija, po katerih se izobražujejo bodoči častniki,

- razvoj neposredno podprte znanstvenoraziskovalne dejavnosti na področju vojaških ved in vojaške znanosti.

\subsection{Višje strokovno izobraževanje}

Višje strokovno izobraževanje dopolnjuje oziroma zaokroža ponudbo v terciarnem izobraževanju in je postalo njegov nepogrešljivi del. Čedalje pogosteje se tudi v Evropi poudarja nujnost kratkega terciarnega izobraževanja (kratki terciarni programi), imenovanega »tertiary short cycle education« oziroma »sub-degree level« ali »short cycle level«, krajše terciarno izobraževanje. Ta vrsta izobraževanja je v bolonjskem procesu upoštevana kot most med njim in stopenjskim (visokošolskim) študijem. Seveda je treba za to razvijati sistem kreditnih točk, prilog k diplomi, akreditacijo programov in sistem kakovosti.

Možnosti za integracijo VIU v javni sistem visokošolskega izobraževanja na tej stopnji so:

- nadaljevanje razvoja vojaških modulov v programih javnih višješolskih ustanov, ki bi zagotavljali razvoj in vključitev programov izobraževanja podčastnikov na drugi stopnji poveljniško-štabnega šolanja, hkrati pa bi ponujali možnost študija na drugi bolonjski stopnji;

- razvoj neposredno podprte znanstvenoraziskovalne dejavnosti na področju vojaških ved in vojaške znanosti.

\subsection{Srednje tehniško in srednje strokovno izobraževanje}

Srednje strokovno oziroma srednje tehniško izobraževanje je namenjeno učencem, ki so uspešno končali osnovno šolo ali nižjo poklicno šolo, in traja štiri leta. Po eni strani omogoča poklicno usposobljenost, po drugi pa ustrezno pripravo za 
nadaljnji študij v programih višjega in visokega strokovnega izobraževanja. Srednje strokovno izobraževanje vključuje v precej enakovrednem obsegu splošnoizobraževalne predmete in strokovno-teoretične predmete ter praktično izobraževanje $\mathrm{v}$ neposrednem delovnem procesu. Omenim naj, da programi omogočajo izbiro in s tem usmerjanje dijakov v ožja in specialna strokovna področja. Izobraževanje se konča s poklicno maturo, ki je sestavljena iz obveznih predmetov (slovenski jezik in strokovno-teoretični predmet) ter izbirnih predmetov (tuji jezik ali matematika ter izdelek oziroma storitev z zagovorom ali seminarska naloga ali ustni ali pisni izpit iz četrtega predmeta).

Možnosti za integracijo VIU v javni sistem izobraževanja na tej stopnji:

- vključitev splošnega in teoretičnega dela predvsem OVSU za VED vojak v programe vojaškega šolanja, vključenega $\mathrm{v}$ javni sistem;

- vključitev TVSU kot dela obvezne delovne prakse v srednje strokovne šole, v katerih bi se oblikovali deli programov šolanja kadra za SV;

- če bi se odločili za razvoj nove kategorije podčastnikov - tehnični podčastniki, bi v okviru srednjih strokovnih šol lahko opravili splošni teoretični del programa šole za podčastnike.

\section{PROGRAMI VIU, PRIMERNI ZA VKLJUČITEV V JAVNI SISTEM} IZOBRAŽEVANJA

\subsection{Temeljno vojaškostrokovno usposabljanje}

Temeljno vojaškostrokovno usposabljanje (TVSU) je osrednji program CU. Program v prvem delu zagotavlja pridobivanje skupnega jedra veščin, navad in znanja, ki jih potrebuje kandidat za vojaško osebo za delo v vojski in preživetje na bojišču. Na tej podlagi se pozneje nadgrajuje njegova usposobljenost z znanjem in veščinami, ki jih kandidat potrebuje za poklicno kariero v vojski ali za opravljanje nalog v rezervni sestavi SV. Program je oblikovan iz potreb, izhajajočih iz značilnosti vojaškega poklica v sodobnih oboroženih silah, ki zahtevajo dobro usposobljenega pripadnika oboroženih sil, in iz značilnosti poklicne vojske, dopolnjene s pogodbeno rezervo, ter značilnosti sodobnega bojišča.

Prav zaradi tega (temeljni elementi vojaškega poklica) je TVSU prvi izmed programov, ki ga je mogoče in treba vključiti v javni sistem izobraževanja. Deloma so tu že vidni uspehi, kot je navedeno v enem prejšnjih poglavij. Prav model, ki se izvaja, je tisti, ki bi bil lahko uveden na vseh ravneh.

Ker TVSU prinaša učenje veščin, je primerno, da se v javne programe izobraževanja uvede kot del obveznega praktičnega usposabljanja (delovne prakse), ki se izvaja tako na srednji strokovni kot tudi na univerzitetni ravni. 


\subsection{Programi osnovnega vojaškostrokovnega usposabljanja}

Programi osnovnega vojaškostrokovnega usposabljanja (OVSU) za različne vojaške evidenčne dolžnosti (VED) vojakov sestavljajo interno vojaško izobraževanje, katerega del bi skladno $\mathrm{z}$ veljavno javno zakonodajo $\mathrm{v}$ resnici lahko predstavljal pridobivanje nacionalnih poklicnih kvalifikacij. Z uveljavljanjem nacionalnih poklicnih kvalifikacij bi bilo zagotovljeno, da bi ta del internega vojaškega izobraževanja prerasel v javno priznano usposabljanje.

Predvsem programi srednjega strokovnega izobraževanja različnih smeri s strokovnim delom programa in tretjim delom, ki predstavlja tako imenovani prosti kurikulum, dajejo veliko možnosti za integracijo dela OVSU za VED vojak v redne javne programe izobraževanja.

\subsection{Program OVSIU častnikov}

Program OVSIU je osrednji program na Šoli za častnike, po katerem se izobražujejo bodoči častniki. Slušatelji z njim pridobijo temeljno splošno, vojaško in specialistično znanje ter praktične veščine, ki zagotavljajo uspešno izvajanje vseh nalog v slovenskem in mednarodnem vojaškem okolju. Slušatelji se pripravljajo za prevzem in vodenje enot (vod) rodov in služb.

Tudi ta program je trenutno pretežno veščinsko naravnan. Deloma splošni, predvsem pa teoretični del programa bi bilo treba vključiti v programe $\mathrm{v}$ javnem sistemu izobraževanja, specialistični, predvsem veščinski del, pa bo moral ostati kot interno izobraževanje, $\mathrm{s}$ katerim bomo zagotovili, da bo posameznik imel znanje in veščine za poveljevanje različnim vrstam vodov oziroma za opravljanje različnih začetnih častniških dolžnosti.

Moje stališče je, da bi morali TVSU in OVSIU častnikov organizirati kot kombinacijo štipendiranja oziroma zaposlitve, bivanja v študentskih domovih, kreditnega dodiplomskega izobraževanja in poletnega praktičnega usposabljanja (terensko usposabljanje, pridobivanje vojaških veščin, delovna praksa, praktične vaje pri predmetu taktika) ter pri tem zagotoviti tak sistem pridobivanja znanja, da bodo kandidati v dodiplomskem izobraževanju (za določen poklicni profil na izbrani fakulteti) pridobili tudi temeljno vojaško znanje in vojaške veščine.

Ideja o programu študija vojaških ved temelji na zamisli o enem programu z več jedri študija. Osrednje jedro bi bili predmeti vojaškega študija, druga jedra pa bi za bodoče častnike SV zagotavljala izbirne predmete tudi za druge programe študija na drugih fakultetah ${ }^{6}$.

\footnotetext{
Več o tem tudi Toš, D., 2008. Vojaški izobraževalni sistem - realnost ali muha enodnevnica. V: Bilten Slovenske vojske, maj $2008-10 /$ st. 1, stran 97-121.
} 
Splošni poklicni profili začetnih dolžnosti

častnika so:

\begin{tabular}{|c|c|c|}
\hline Rod - služba SV & Primerni temeljni študij & Opomba \\
\hline pehota & $\begin{array}{l}\text { obramboslovne vede, } \\
\text { varstvoslovne vede, } \\
\text { vojaške vede }\end{array}$ & \\
\hline $\begin{array}{l}\text { oklepne enote } \\
\text { mehanizirane enote } \\
\text { motorizirane enote }\end{array}$ & strojništvo & \\
\hline artilerija & strojništvo & \\
\hline inženirstvo & gradbeništvo & smer nizke gradnje \\
\hline zveze & elektrotehnika & smer telekomunikacije \\
\hline RKBO & $\begin{array}{l}\text { kemija in kemijska tehnologija, } \\
\text { biotehniške vede }\end{array}$ & \\
\hline ZO, raketne enote $Z O$ & tehnične smeri & $\begin{array}{l}\text { smer elektrotehnika in/ali } \\
\text { avtomatizacija procesov }\end{array}$ \\
\hline \multirow{2}{*}{ ZO, nadzor zračnega prostora } & \multirow{2}{*}{$\begin{array}{l}\text { tehnične smeri, } \\
\text { promet in logistika } \\
\text { (pomorstvo in promet) }\end{array}$} & $\begin{array}{l}\text { smeri elektrotehnika } \\
\text { avtomatizacija procesov, } \\
\text { računalništvo in informatika }\end{array}$ \\
\hline & & smer zračni promet \\
\hline letalstvo - piloti & strojništvo & smer letalstvo \\
\hline letalstvo - inženirji & strojništvo & smer letalstvo \\
\hline pomorstvo & pomorstvo in promet, & \\
\hline logistika - oskrba & logistika & \\
\hline logistika - vzdrževanje & strojništvo & \\
\hline logistika - premiki in transport & $\begin{array}{l}\text { pomorstvo in promet, } \\
\text { logistika }\end{array}$ & smer tehnologija prometa \\
\hline logistika - zdravstvena služba & $\begin{array}{l}\text { medicina, } \\
\text { zdravstvo }\end{array}$ & \\
\hline logistika - finančna služba & ekonomija & \\
\hline logistika - infrastruktura & gradbeništvo & \\
\hline
\end{tabular}

Izbirna jedra bi bili predmeti v šestih skupinah:

\section{1. skupina - vojaške vede:}

- teorija taktike in drugih vojaških ved,

- pehotni (sodobni) oborožitveni sistemi,

- vojaški/obrambni menedžment in vojaško poveljevanje,

- polemologija,

- obrambni in varnostni ter primerjalni obrambni sistemi; 
2. skupina - vojaške veščine (20 KT):

- vojaški praktikum 1, 2, 3, 4 - štirikrat po tri tedne,

- pehotna oborožitev s poukom streljanja,

- taktika (veščina),

- mednarodno vojaško pravo in pravo za častnike;

3. skupina - družboslovne vede:

- obča politologija,

- politični sistem RS in temelji državne ureditve,

- mednarodni odnosi z osnovami prava oboroženih spopadov,

- slovenski jezik, slovensko vojaško izrazje in osnove komunikacije;

4. skupina - civilno-vojaške vede:

- splošna vojaška zgodovina in vojaška zgodovina Slovenije in Slovencev,

- socialna in politična ter vojaška psihologija,

- sociologija in politologija vojske,

- vojaška geografija, kartografija in topografija,

- informatizacija sodobnih oboroženih sil in prostorska informatika;

5. skupina - naravoslovne vede:

- matematika,

- tehnološki sistemi z osnovami ekologije;

6. skupina - tehniške vede

- osnove konstrukcije in materialov;

- temelji mehanike $\mathrm{z}$ balistiko;

- osnove mehatronike.

Osrednje jedro študija, katerega glavni del bi bilo visoko strokovno šolanje častnikov pehote, bi obsegal področja študija:

\section{1. ekonomske vede:}

- temelji ekonomije;

2. politologija:

- obča politologija, politološka zgodovina in primerjalni politični sistem,

- politični sistem RS in temelji državne ureditve;

\section{3. mednarodni odnosi:}

- mednarodni odnosi z osnovami prava oboroženih spopadov,

- mednarodne integracije in varnost v mednarodnih odnosih;

\section{4. metodologija in informatika:}

- metode družboslovnega raziskovanja,

- statistika,

- uvod v družboslovno informatiko; 


\section{5. psihologija:}

- obča psihologija,

- sociološka in politična psihologija;

\section{6. sociologija:}

- obča sociologija,

- sociologija organizacije;

\section{7. organizacijske vede in menedžment:}

- osnove organizacije in menedžmenta,

- splošni in strateški menedžment,

- ravnanje z ljudmi;

\section{8. jezikoslovno izobraževanje:}

- tuji jezik,

- slovenski jezik in slovensko vojaško izrazje,

- komunikologija (javno nastopanje, retorika in komuniciranje);

\section{9. upravno pravo in javna uprava:}

- upravno pravo in javna uprava;

\section{0. civilna obramba:}

- teorija civilne obrambe,

- kriza, krizno upravljanje in sodobna varnost;

\section{1. filozofija:}

- filozofija in etika;

\section{2. športna vzgoja.}

\subsection{Program OVSIU podčastnikov}

Osrednji program ŠPČ je program OVSIU kandidatov za podčastnike, ki se izvaja v dveh fazah. Prva obsega pridobivanje splošnega vojaškostrokovnega znanja in vojaških veščin, druga pa zagotavlja pridobivanje specialističnega vojaškostrokovnega znanja o ustreznem rodu ali službi. Ker gre za izrazito veščinsko usmerjeno izobraževanje, menimo, da to šolanje lahko ostane v internem sistemu izobraževanja SV.

Zaradi posebne dolžnosti, katere kakovostno opravljanje je v pomembnem delu pri podčastniku odvisno od praktičnih izkušenj, ki jih posameznik lahko pridobi le kot vojak, vodja tima, skupine, posadke itn., se pri OVSIU podčastnikov ni mogoče opreti na srednješolsko izobraževanje. Nekatere vojske v svetu sicer delajo izjeme pri nekaterih tipih podčastnikov, pri katerih je v primerjavi z izkušnjami v prednosti strokovno znanje (tako imenovani tehnični podčastniki), vendar se v SV za takšen razvoj podčastnikov (̌̌e) nismo odločili. 


\subsection{Programi poveljniško-štabnega šolanja}

Poveljniško-štabna šola izvaja najzahtevnejši del nadaljevalnega vojaškostrokovnega izobraževanja oziroma usposabljanja častnikov Slovenske vojske za upravljanje upravno-strokovnih, štabnih, menedžerskih in poveljniških dolžnosti. Šola izvaja večmesečno izobraževanje in usposabljanje poveljstev, poveljnikov in štabnih častnikov za poveljevanje enotam ter opravljanje štabnih funkcij $v$ generalštabu in na poveljstvih SV, pa tudi na poveljstvih združenih operativnih sestav mirovnih sil.

Poveljniško-štabno šolanje podčastnikov poteka na treh ravneh (nadaljevalno, višje in visoko) prav tako poveljniško-štabno šolanje častnikov (štabno, višještabno, generalštabno).

Programi izobraževanja in usposabljanja obsegajo pridobivanje znanja in navad po standardih, ki omogočajo in zagotavljajo povezljivost SV z vojskami držav članic Nata. Temeljni poudarek je na taktiki, operatiki in vojaškem voditeljstvu ter štabnem delu. Pri zahtevnejšem vojaškostrokovnem izobraževanju poveljnikov in častnikov na poveljstvih in $\mathrm{v}$ štabih prihaja $\mathrm{v}$ celotni Evropi do hitrih sprememb. Te so posledica spreminjajočih se obrambnodoktrinarnih in strateških opredelitev v programih ter metodah in pristopih izobraževanja.

Prva stopnja poveljniškega šolanja je $\mathrm{v}$ obeh primerih (častniškem in podčastniškem) izrazito veščinsko naravnana, zato bi bilo po mojem mnenju tudi v prihodnje treba ohraniti te programe v internem izobraževalnem sistemu SV. Predvidevati je mogoče, da bi bilo glede na vsebino, obseg in zahtevnost šolanja mogoče programe ovrednotiti s 15 do 20 kreditnimi točkami po ECTS (European Credit Transfer and Accumulation System), ki bi jih seveda bilo mogoče uveljaviti na drugi stopnji poveljniško-štabnega šolanja ${ }^{7}$.

$\mathrm{Z}$ drugo stopnjo poveljniško-štabnega šolanja $\mathrm{v}$ obeh primerih (častniškem in podčastniškem) je treba nadaljevati vključevanje $\mathrm{v}$ javni sistem izobraževanja, tako da bo neposredno povezana s študijem $\mathrm{v}$ javnem sistemu izobraževanja. Gre za študij na drugi bolonjski stopnji za šolanje častnika ter izobraževanje na visoki strokovni stopnji za podčastnika. $\mathrm{V}$ obeh primerih bi bilo na tej stopnji izobraževanja treba začeti uveljavljati kreditne točke, pridobljene na prvi stopnji poveljniškega šolanja. Na stopnji višjega štabnega VIU častnika je treba ohraniti strokovno in vojaško specializacijo posameznika. VIU mora biti na tej stopnji usmerjen v študij splošnih vojaških ter vojaških družboslovnih in drugih ved. Osebno specializacijo posameznika je treba ohraniti na štirih ali petih smereh v strokah, pomembnih za razvoj in vodenje vojske (splošni menedžment, logistika, kadri, informatika in telekomunikacije, mednarodni odnosi itn.), kar v nadaljevanju pomeni usmeritev posameznika v posamezno dejavnost $\mathrm{v}$ vojski.

Več o tem tudi v Toš, D., 2008. Vojaški izobraževalni sistem - realnost ali muha enodnevnica. V: Bilten

Slovenske vojske, maj 2008-10/št. 1, stran 97-121. 
Tudi šolanje podčastnika na tej stopnji bi moralo biti modelirano in vsebinsko oblikovano tako, da podčastnik poleg civilnega pridobi tudi vojaško znanje in javno priznano listino. Podčastniki bi se glede na potrebe SV izobrazili po ustreznih programih višjih strokovnih šol, ki strokovno podpirajo opravljanje predvidene dolžnosti v SV (tehnične smeri, logistika in promet, informatika in telekomunikacije, policijska akademija, organizacija itn.). Slušatelji bi se usposobili tudi v vojaških predmetih in tako poleg javno priznane višje stopnje strokovne izobrazbe pridobili vojaško znanje za opravljanje dolžnosti višjih podčastnikov.

Tretja stopnja poveljniškega šolanja častnikov je generalštabno šolanje častnikov, ki bi ga bilo v javni sistem izobraževanja treba vključiti tako, da bi omogočalo poglobljeno izobraževanje častnikov. Na tej stopnji bi ohranjali le še študij strateškega menedžmenta in študij na področju nacionalnega obrambno-varnostnega sistema oziroma zadev. Lahko se nadgradi tudi znanje o strateškem vodenju (predvsem mirnodobno, pa tudi vojno, ravnanje z viri, pravo, strateško odločanje itn.), študij elementov nacionalne moči in njihov vpliv na nacionalno varnost (osnovni: ekonomija, diplomacija, vojska, informacijska dejavnost; dodatni: kultura, zavezništva, okolje ... notranja in zunanja varnost itn.), študij nacionalne in mednarodne varnosti (obrambno-varnostni sistem - nacionalni, zavezniški in mednarodni) ter seveda vojaške strategije, velike strategije in operatike.

Tretja stopnja šolanja podčastnikov predstavlja nadaljevanje šolanja na dodiplomski stopnji, pri čemer se podčastniki usposobijo za opravljanje najvišjih podčastniških dolžnosti. Poudarek bi moral biti na študiju razvoja in uporabe oboroženih sil v globalnem mednarodnem okolju ter podpori vodenju sodobne, profesionalne vojaške sile v okviru kolektivne obrambe v informacijski družbi.

Menim, da morata tako generalštabno izobraževanje častnika kot tretja stopnja šolanja podčastnika posamezniku omogočati pridobivanje kreditnih točk, priznanih v javnem sistemu izobraževanja, ki jih posameznik uveljavlja, če se samostojno odloča za nadaljevanje razvoja na akademski ravni.

Res je, da je del modela vključevanja poveljniško-štabnega šolanja že zagotovljen, je pa treba nekatere stvari še nadgraditi in dopolniti. Vsekakor za nadaljnji razvoj potrebujemo program visokega šolanja za podčastnike, ki bo zagotavljal šolanje za večino podčastnikov. Tisti, ki bodo potrebovali znanje z drugih strokovnih šol, pa bodo splošni strokovni del dobili tam. Nekoliko boljše so razmere pri zagotavljanju vključevanja poveljniško-štabnega šolanja v javni sistem izobraževanja na drugi stopnji. V nekaj generacijah tega šolanja je bilo zagotovljeno, da so skupno jedro vojaškostrokovnega dela priznale tri ustanove. Sedanje stanje ima nekaj slabosti, ki jih bo v nadaljevanju treba odpraviti. Bistvena slabost je, da program poveljniško-štabnega šolanja častnikov na drugi stopnji ne omogoča, da bi nekdo opravil vojaški del šolanja, ne da bi se vključil v javni program podiplomskega izobraževanja, kar bi ne nazadnje morala biti posameznikova izbira. Je pa res, da bi sistem moral preprečiti situacije, ko se na primer posameznik odloči za vojaški del študija, 
pozneje pa se premisli in ob delu študira za pridobitev stopnje izobrazbe na smeri, »ki mu bolj ustreza«. Tudi ob tem primeru je mogoče razumeti, da pri izobraževanju častnika v javnem izobraževalnem sistemu ni bistvo le v pridobivanju stopnje izobrazbe, temveč v vsebini študija.

Posebno pomembno se mi zdi poudariti, da se mora predvsem poveljniško-štabno šolanje opreti na močne tuje javne vojaške izobraževalne ustanove držav Nata in EU.

Sklep Težava je v kritičnem razmišljanju in znanju. Tu se zapletemo v zanko. Brez znanja ne uspemo zgraditi ustreznega sistema, brez takega sistema pa ni priložnosti za razvoj in nastanek novega eksplicitnega znanja.

Kaj po mojem mnenju najbolj negativno vpliva na razvoj sistema VIU v Slovenski vojski in slabša razvojne pobude in energijo?

V resnici ni najpomembnejše, vendar naj začnem z nekritičnim odnosom do izobraževanja in usposabljanja $\mathrm{v}$ tujini ter odnosom do prenosa tam pridobljenega znanja. Povsem razumljivo je, da mlad sistem, kot je naš, išče znanje in rešitve v sodobnih in razvitih vojaških sistemih $\mathrm{v}$ tujini. Narobe je, da rešitve, ki v tujih oboroženih silah dajejo dobre rezultate, poskušamo preslikati v našo vojsko, in narobe je, da posamezniki, šolani v tujini, sami nekritično ugotovijo, da nič tega, kar so pridobili, ni uporabno v domovini. Kaj hitro ugotovimo, da nekatere preslikane rešitve v naši vojski ne dosegajo rezultatov. In pozneje nekritično, ne da bi poskusili upoštevati širše okoliščine, v katerih rešitve v tujini delujejo, ne razumemo, zakaj. Pa bi morali vedeti, kaj je treba narediti. Najprej je treba na vseh ravneh začeti v tujino pošiljati ljudi, ki v celoti razumejo razloge, zakaj so tja napoteni. Tudi tistega, da je njihovo poslanstvo po vrnitvi v domovino tudi prenos znanja na druge.

Viri. Strinjati se moramo, da je morebiti dopustno razmišljati, da delodajalec, če želi izobraževalne programe po svoji meri, sofinancira razvojne procese, ki so potrebni, da novi predmeti in programi nastanejo. Nedopustno pa je, da je pozneje izvedbo teh programov treba financirati. Če je treba vsako leto v javnem sistemu izšolati štirideset častnikov, šestdeset podčastnikov in tristo vojakov, katerih del šolanja poteka v javnem izobraževalnem sistemu, se pojavlja legitimno vprašanje, zakaj se na primer lahko pet častnikov pilotov izšola $\mathrm{v}$ javnem sistemu, drugo šolanje pa plača obrambni sistem. Zakaj lahko SV na primer pet politologov (obramboslovcev brez vojaškega modula) dobi »brezplačno«, dele izobraževanja obramboslovcev (z vojaškim modulom) pa mora sofinancirati. Kljub temu da je tak pristop nekako nesmiseln, ni bistvo v nesmislu. Bistvo je, da je ta pristop v sebi nestabilen, kar je v izobraževalnih sistemih nedopustno. Če kdo meni, da za vrhunski menedžment vojske obstaja velika dilema, ko mora ob pomanjkanju sredstev izbrati med financiranjem nujnih nalog temeljnega poslanstva vojske in izobraževanjem kandidatov za zaposlitev, se po moji presoji moti. 
Kader. Ali je izbira kadra za izvajanje procesov in delo v sistemu VIU načrtna in ustrezna? Tega vprašanja nekako in nikakor ne želimo izpostaviti. Da bi prišli do primernejših rešitev, bi po moji presoji bilo treba v sistemu določiti več različnih profilov. Kadri za menedžment šole in za podporo delovanju se vsekakor lahko vključujejo v izobraževanje iz operativnega dela vojske in se vračajo v enote. Če pa pogledamo na strokovnjake različnih posebnih vojaških strok, pa je treba izluščiti tiste, ki se v sistem VIU vključijo, se tam razvijajo in kot strokovnjaki tam tudi rastejo in ostanejo. Drugi vidik strokovne podpore pa morajo v sistemu VIU predstavljati častniki in podčastniki iz poveljstev in enot, ki se vanj vključujejo kot vrhunski strokovnjaki, ki obvladujejo tudi druge vidike stroke - izkušnje prakse in praktične ter stvarne rešitve strokovnih vprašanj.

Sploh si ne upam pomisliti, kašno usodo bi v tem obdobju doživljale pobude, ki jih bo v bližnji prihodnosti treba analizirati in začeti iskati rešitve. Države, večje kot je naša, se odločajo za racionalizacijo vojaških in drugih (varnostnih) sistemov izobraževanja in usposabljanja, in sicer tako, da oblikujejo skupna jedra znanja in skupne programe, na koncu je mogoče najti tudi že skupne ustanove (tudi izobraževalne) v nacionalnem obrambno-varnostnem sistemu. Ne gre samo za iskanje komplementarnosti med javnim in internim izobraževalnim sistemom, kar povečuje možnost gibanja kadra na trgu delovne sile, temveč za iskanje strokovne povezljivosti med različnimi strokovnimi in poklicnimi profili, kar racionalizira formalne organe države, zmanjšuje stroške in ne nazadnje omogoča prehode med različnimi podsistemi v nacionalnem obrambno-varnostnem sistemu (vojska, policija, zaščita in reševanje, gasilci itn. $)^{8}$.

Članek sem začel z iskrico, objavljeno v Dnevniku sredi leta 2009. Gledano s tega zornega kota je škoda, da se projekta razvoja slovenskega vojaškega šolstva nismo lotili širše. Prepričan sem, da bi nam lahko uspelo veliko več. Ne vem, kje se je zataknilo. Ali smo bili v vojski premalo iniciativni? Tudi verjetno, ampak glede na to, da bi nam politika morala povedati kako ...

Naj sklenem članek z umikom. Priznam, da sem imel najprej namero, da v članku poskušam prikazati svoj pogled na Fakulteto za družbene vede, ki ima s svojo Katedro za obramboslovje pri razvoju vojske in podsistema VIU pomembno vlogo, verjetno večjo kot je videti, pa če hočemo to priznati ali ne. Da bi se opredelili do te vloge in postavili predznak, bi zaradi korektnosti morali opraviti natančnejšo analizo njihovega teoretičnega in praktičnega delovanja ter na tej podlagi z družboslovno sprejemljivimi metodami oceniti vpliv na razvoj Slovenske vojske. Zakaj nisem tega storil, zakaj sem se umaknil? Verjetno bi za kaj takega potreboval več dela in časa, kot je bilo vloženih v ta članek. Pisanje o tem bi verjetno moral začeti z vprašanjem, kaj bi se na področju razvoja vojaškega šolstva zgodilo, če po osamosvojitvi leta 1991 v slovenskem prostoru ne bi delovala Katedra za obramboslovje. Imam občutek, da mi pisanje odgovorov nikakor ne bi šlo.

8 Glej tudi Toš, D., 2007. Obrambno in varnostno izobraževanje v nacionalnem obrambno-varnostnem sistemu $R$ Slovenije, seminarski delo. Poljče, 2003. 
1. Furlan, B., in skupina avtorjev, 2006. Vojaška doktrina. Ljubljana: Defensor.

2. Izhodišča za oblikovanje v sistem javnega izobraževanja integrirane vojaške izobraževalne institucije (603-105/2008-3 z dne 16. 8. 2008).

3. Kastelic, G., 2008. Zgodovinski pregled izobraževanja in usposabljanja častnikov na Slovenskem. V: Bilten Slovenske vojske, maj 2008-10/st. 1, str. 11-24.

4. Koncept sistema vojaškega izobraževanja in usposabljanja v SV (dokument GŠSV, 811-016/03-4 z dne 9. 7. 2003).

5. »Motiv«, Poročilo o izvedbi ciljnega raziskovalnega programa »Model terciarnega izobraževanja za vojsko«. 2007. UP Fakulteta za management Koper.

6. Obvezne usmeritve za preoblikovanje in razvoj sistema VIU v SV (811-01-1/2003-31 z dne 14. 7. 2003).

7. Toš, D., 2003. Obrambno in varnostno izobraževanje v nacionalnem obrambnovarnostnem sistemu R Slovenije, seminarski delo. Poljče.

8. Toš, D., 2008. Vojaški izobraževalni sistem - realnost ali muha enodnevnica. V: Bilten Slovenske vojske, maj 2008-10/št. 1, str. 97-121.

9. Zbornik»Prvi posvet o šolanju častnikov Slovenske vojske». 1994. Republika Slovenija, Ministrstvo za obrambo. Ljubljana. 